\title{
Clinical heterogeneity in hereditary haemorrhagic telangiectasia: are pulmonary arteriovenous malformations more common in families linked to endoglin?
}

\author{
Jonathan N Berg, Alan E Guttmacher, Douglas A Marchuk, Mary E M Porteous
}

A E Guttmacher

\section{Department of Genetics, \\ Duke University \\ Medical Centre, \\ Durham, NC 27710, \\ USA \\ D A Marchuk \\ Correspondence to: Dr Berg.}

Received 23 May 1995 Revised version accepted for publication 16 October 1995

(f Med Genet 1996;33:256-257)

Key words: hereditary haemorrhagic telangiectasia; pulmonary arteriovenous malformation; endoglin.

Hereditary haemorrhagic telangiectasia (HHT), also known as Osler-Rendu-Weber syndrome, is an autosomal dominant vascular dysplasia characterised by mucocutaneous telangiectasis (fig 1) and severe recurrent epistaxes. Pulmonary arteriovenous malforma-

\begin{abstract}
Human Genetics Unit,
University of

Edinburgh,

Western General

Hospital,

Crewe Road,

Edinburgh EH4 2XU,

UK

J N Berg

M E M Porteous

Department of

Pediatrics,

University of Vermont

College of Medicine,

Burlington, VT 05401,

USA

Abstract

Pulmonary arteriovenous malformations (PAVMs) occur in up to $27 \%$ of patients with hereditary haemorrhagic telangiectasia (HHT) and are associated with a rate of paradoxical cerebral embolism at presentation of up to $36 \%$. At least two different loci have been shown for HHT. Mutations in endoglin have been found in some families and the locus designated ORW1. In other families this locus has been excluded. In this paper we confirm that in families linked to ORW1 there is a prevalence of PAVMs among affected members of $29.2 \%$, compared to a prevalence of $2.9 \%$ in families in which this locus has been excluded $\left(\chi^{2}=19 \cdot 2\right.$, $p<0 \cdot 001)$. This information can be used to decide how to screen HHT patients for PAVMs.
\end{abstract}

Families used in this study: source of data and incidence of PAVMs within each family

\begin{tabular}{|c|c|c|c|c|}
\hline $\begin{array}{l}\text { Family source } \\
\text { and reference }\end{array}$ & $\begin{array}{l}\text { Endoglin } \\
(O R W 1) \text { linkage }\end{array}$ & $\begin{array}{l}\text { Assessed by } \\
\text { pulse oximetry }\end{array}$ & $\begin{array}{l}\text { No of affected } \\
\text { family members assessed }\end{array}$ & $\begin{array}{l}\text { No of PAVMs } \\
\text { in those assessed }\end{array}$ \\
\hline $\begin{array}{l}\text { Family } 1^{12} \\
\text { Family } 2^{12} \\
\text { Family } 3^{12} \\
\text { Family } 4^{12} \\
\text { Family } 5^{*} \\
\text { Family } 17^{8} \\
\text { Family } 33^{8} \\
\text { Family } T^{7}\end{array}$ & $\begin{array}{l}\text { No } \\
\text { No } \\
\text { No } \\
\text { No } \\
\text { No } \\
\text { No } \\
\text { No } \\
\text { No }\end{array}$ & $\begin{array}{l}\text { Yes } \\
\text { Yes } \\
\text { No } \\
\text { No } \\
\text { Yes } \\
\text { No } \\
\text { No } \\
\text { Yes }\end{array}$ & $\begin{array}{r}6 \\
8 \\
10 \\
9 \\
13 \\
6 \\
8 \\
9\end{array}$ & $\begin{array}{l}0 \\
0 \\
0 \\
1 \\
0 \\
0 \\
0 \\
1\end{array}$ \\
\hline Family $T^{7}$ & & Total & 69 & $2(2 \cdot 9 \%)$ \\
\hline $\begin{array}{l}\text { Family } 01^{8} \\
\text { Family } 02^{8} \\
\text { Family } 32^{8} \\
\text { Family } 56^{8} \\
\text { Family } 6^{*} \\
\text { Family } 7^{*} \\
\text { Family } \mathrm{F}^{7} \\
\text { Family } \mathrm{A}^{7}\end{array}$ & 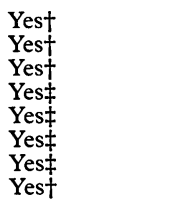 & $\begin{array}{l}\text { No } \\
\text { No } \\
\text { No } \\
\text { No } \\
\text { Yes } \\
\text { Yes } \\
\text { Yes } \\
\text { Yes }\end{array}$ & $\begin{array}{r}45 \\
20 \\
11 \\
6 \\
5 \\
7 \\
9 \\
17\end{array}$ & $\begin{array}{r}13 \\
8 \\
3 \\
2 \\
2 \\
3 \\
3 \\
1\end{array}$ \\
\hline & & Total & 120 & $35(29 \cdot 2 \%)$ \\
\hline
\end{tabular}

In non-ORW 1 linked families linkage was excluded across the candidate interval on multipoint analysis, or by a lod of less than -2 at $\theta=0.02$ with D9S61.

* Family previously unpublished (Porteous and Berg).

t ORW 1 linkage was shown by a lod score of greater than 3 to a marker close to the candidate region.

region. lod obtainable with the family. tions (PAVMs) occur in between $4.8 \%$ and $27 \%{ }^{12}$ of patients. PAVMs may be asymptomatic, but can often cause hypoxaemia and pulmonary haemorrhage. PAVMs also lead to high incidence of cerebral abscesses, and cerebral thromboembolic complications occur in up to $36 \%$ of patients at presentation. ${ }^{3}$ Most authors recommend screening for asymptomatic PAVMs in HHT patients, ${ }^{3-5}$ with occlusion by embolisation of all lesions with a feeding vessel greater than $3 \mathrm{~mm}$.

Two loci for HHT have been identified. The ORW1 locus, mapping to chromosome 9q34, is endoglin, a TGF- $\beta$ binding protein expressed on endothelial cells. ${ }^{6-9}$ Recently, a second locus on $12 \mathrm{q}$ has been reported. ${ }^{1011}$ Several authors have noted a subjectively higher frequency of PAVMs in families showing linkage to ORW $1 .^{81213}$

In this paper we aim to address the size of this difference, using data from three new families (fig 2) and 16 families previously published. ${ }^{71011}$

Diagnosis of HHT in the three new families was made by the presence of two of: recurrent epistaxis, mucocutaneous telangiectasis, and an affected first degree relative. Pulse oximetry was performed according to the method described by Hughes ${ }^{4}$ to detect PAVMs. Three subjects from family 5 had a chest $x$ ray and lung perfusion scans. Clinical details of the thirteen families assessed by our group were all collected before linkage data were available.

For the newly assessed families, microsatellite markers were run using accepted techniques and analysis of results was performed using MLINK or LINKMAP.

Of the 16 families included, eight families are not linked to endoglin on chromosome 9

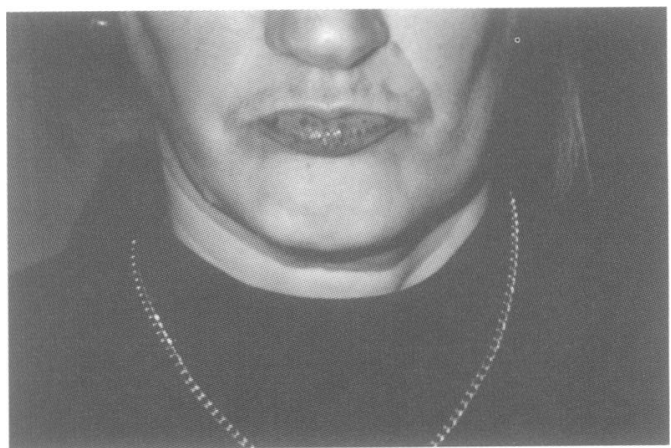

Figure 1 Classical telangiectases on the lips of an HHT patient. 
Family 5

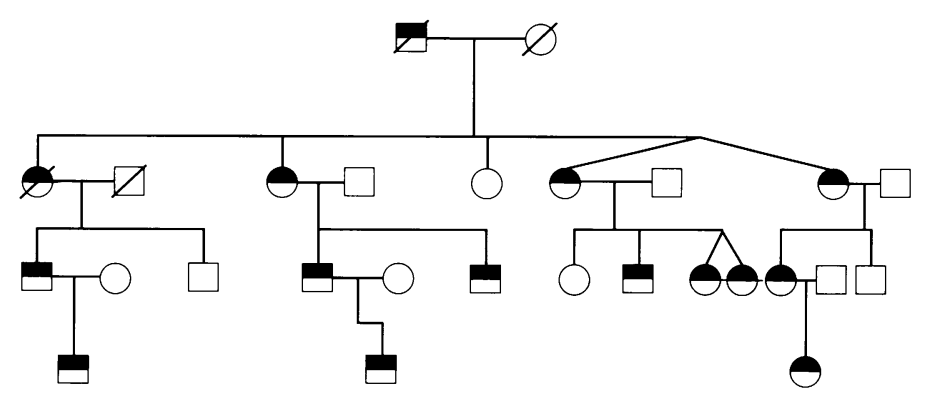

Family 6

Family 7

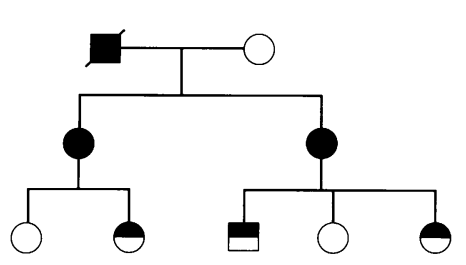

Affected with telangiectasis and epistaxis

Affected with PAVM, telangiectasis, and epistaxis

Obligate carrier, no evidence of $\mathrm{HHT}$

Unaffected

Figure 2 Pedigrees of the three families not previously published.

and eight families show evidence of linkage. The majority of people in this group (93/120) came from families large enough to achieve a lod score of greater than 3. The data are summarised in the table.

In the families linked to endoglin, 35/120 $(29 \cdot 2 \%)$ had pulmonary arteriovenous malformations. In the unlinked families, $2 / 69$ $(2 \cdot 9 \%)$ had PAVMs. The difference between these two groups is highly significant $\left(\chi^{2}=19 \cdot 2\right.$, $1 \mathrm{df}, \mathrm{p}<0.001$ ).

In the endoglin linked group many of the patients had symptomatic PAVMs. There may be several small asymptomatic PAVMs in the non-endoglin population, even though $36 / 69$ were screened by pulse oximetry. This is an unlikely source of bias as more careful screening of the endoglin population would also be ex- pected to turn up a greater number of asymptomatic PAVMs. All families were assessed "blind" before linkage data were available.

The observed difference in PAVM frequency is a biologically plausible finding. Endoglin may well have a role in the development of pulmonary vasculature which is not shared by the other genes in which mutations can cause HHT.

As all those with HHT are at some risk of having a PAVM, it is important to offer screening to all patients, at least by the method of Hughes ${ }^{4}$ using supine and erect pulse oximetry and chest $x$ ray.

With members of endoglin linked families having a $29 \cdot 2 \%$ incidence of PAVMs, it is particularly important to target screening on (1) patients from families with HHT linked to endoglin on $9 q 34$, (2) patients who have a family history of PAVMs. For these patients, we feel that formal arterial oxygen measurement and measurement of right to left pulmonary shunt fraction using the $100 \%$ oxygen method $^{5}$ may be justified.

Firstly we wish to thank all the patients whose participation made this study possible. We also wish to thank Professor J M $B$ Hughes for assessing members of family 5 for PAVMs and Bernadette Farren for helping to collect samples. Particular thanks are due to Catherine Cookson, who has funded much of this work.

1 Porteous MEM, Burn J, Proctor SJ. Hereditary haemorrhagic telangiectasia: a clinical analysis. $\mathcal{F}$ Med Genet 1992;29:527-30.

2 Plauchu $\mathrm{H}$, de Chadarevian JP, Bideau A, et al. Age-related clinical profile of hereditary haemorrhagic telangiectasia in an epidemiologically recruited population. $\mathrm{Am} \mathcal{F} \mathrm{Med}$

3 White RI Jr, Lynch-Nyhan A, Terry P, et al. Pulmonary arteriovenous malformations: techniques and long term outcome of embolotherapy. Radiology 1988;169:663-9.

4 Hughes JMB. Intrapulmonary shunts: coils to transplantation. $\mathcal{f} R C$ Physicians Lond 1994;28:247-53.

5 Haitjema TJ, Overtoom TTh, Westermann CJJ, et al. Embolisation of pulmonary arteriovenous malformations: results and follow up in 32 patients. Thorax 1995;50:719-23.

6 McDonald MT, Papenberg KA, Ghosh S, et al A disease locus for hereditary haemoric telangiectasia maps to locus for hereditary haemorrhagic telangiectasia maps

7 Shovlin CL, Hughes JMB, Tuddenham EGD, et al. A gene for hereditary haemorrhagic telangiectasia maps to gene for hereditary haemorrhagic telangiectasia
chromosome $9 \mathrm{q} 3$. Nature Genet 1994;6:205-9.

8 McAllister KA, Grogg KM, Johnson DW, et al. Endoglin, a TGF- $\beta$ binding protein of endothelial cells, is the gene for hereditary haemorrhagic telangiectasia type 1. Nature Genet 1994;8:345-51

9 Heutink P, Haitjema T, Breedveld GJ, et al. Linkage of hereditary haemorrhagic telangiectasia to $9 \mathrm{q} 34$ and evidence for locus heterogeneity. F Med Genet 1994;31:933-6.

10 Vincent P, Plauchu H, Hazan J, et al. A third locus for hereditary haemorrhagic telangiectasia maps to $12 \mathrm{q}$. Hum Mol Genet 1995;5:945-50.

11 Johnson DW, Berg JN, Gallione C, et al. A second locus for hereditary haemorrhagic telangiectasia maps to chromosome 12. Genome Res 1995;5:21-8.

12 Porteous MEM, Curtis A, Williams O, et al. Genetic heterogeneity in hereditary haemorrhagic telangiectasia. $\mathcal{f ~ M e d}$ Genet 1994;31:925-6.

13 McAllister KA, Lennon F, Bowles-Bieseckker B, et al. Genetic heterogeneity in hereditary haemorrhagic telangiectasia: possible correlation with clinical phenotype.
$\mathcal{F}$ Med Genet 1994;31:927-32. 